Article

\title{
Stygobiont Diversity in the San Marcos Artesian Well and Edwards Aquifer Groundwater Ecosystem, Texas, USA
}

\author{
Benjamin T. Hutchins ${ }^{1, *(\mathbb{D})}$, J. Randy Gibson ${ }^{2}$, Peter H. Diaz ${ }^{3}$ and Benjamin F. Schwartz ${ }^{1,4}$ (D) \\ 1 Edwards Aquifer Research and Data Center, Texas State University, 601 University Dr., \\ San Marcos, TX 78666, USA; bs37@txstate.edu \\ 2 U.S. Fish and Wildlife Service, San Marcos Aquatic Resources Center, 500 E. McCarty Ln., \\ San Marcos, TX 78666, USA; randy_gibson@fws.gov \\ 3 U.S. Fish and Wildlife Service, Texas Fish and Wildlife Conservation Office, 500 E. McCarty Ln., \\ San Marcos, TX 78666, USA; pete_diaz@fws.gov \\ 4 Department of Biology, Texas State University, 601 University Dr., San Marcos, TX 78666, USA \\ * Correspondence: bh1333@txstate.edu
}

check for

updates

Citation: Hutchins, B.T.; Gibson, J.R.; Diaz, P.H.; Schwartz, B.F. Stygobiont Diversity in the San Marcos Artesian Well and Edwards Aquifer

Groundwater Ecosystem, Texas, USA. Diversity 2021, 13, 234. https:// doi.org/10.3390/d13060234

Academic Editors: Michael Wink, Tanja Pipan, David C. Culver and Louis Deharveng

Received: 22 April 2021

Accepted: 20 May 2021

Published: 26 May 2021

Publisher's Note: MDPI stays neutral with regard to jurisdictional claims in published maps and institutional affiliations.

Copyright: (c) 2021 by the authors. Licensee MDPI, Basel, Switzerland. This article is an open access article distributed under the terms and conditions of the Creative Commons Attribution (CC BY) license (https:// creativecommons.org/licenses/by/ $4.0 /)$.

\begin{abstract}
The Edwards Aquifer and related Edwards-Trinity Aquifer of Central Texas, USA, is a global hotspot of stygobiont biodiversity. We summarize 125 years of biological investigation at the San Marcos Artesian Well (SMAW), the best studied and most biodiverse groundwater site (55 stygobiont taxa: 39 described and 16 undescribed) within the Edwards Aquifer Groundwater Ecosystem. Cluster analysis and redundancy analysis (RDA) incorporating temporally derived, distance-based Moran's Eigenvector Mapping (dbMem) illustrate temporal dynamics in community composition in 85 high-frequency samples from the SMAW. Although hydraulic variability related to precipitation and discharge partially explained changes in community composition at the SMAW, a large amount of temporal autocorrelation between samples remains unexplained. We summarize potential mechanisms by which hydraulic changes can affect community structure in deep, phreatic karst aquifers. We also compile information on 12 other Edwards and Edwards-Trinity Aquifer sites with 10 or more documented stygobionts and used distance-based RDA to assess the relative influences of distance and site type on three measures of $\beta$-diversity. Distance between sites was the most important predictor of total dissimilarity and replacement, although site type was also important. Species richness difference was not predicted by either distance or site type.
\end{abstract}

Keywords: phreatic karst aquifer; stygobite; species richness; temporal dynamics; beta-diversity

\section{Introduction}

The karstic Edwards Aquifer of Central Texas (USA) supplies water for more than 2 million people [1] and is recognized for high stygobiont biodiversity [2]. The 10,500 $\mathrm{km}^{2}$ Edwards Aquifer occurs in a broad arc of Cretaceous limestones that stretch approximately $400 \mathrm{~km}$ across Central Texas, USA, and is hydrologically connected to the $91,744 \mathrm{~km}^{2}$ Edwards-Trinity Aquifer (Figure 1). Edwards-equivalent limestones also extend into northern Coahuila, Mexico [3]. Late Cretaceous through early Miocene uplift of the Edwards Plateau exposed Edwards limestones along the Balcones Fault Zone: a series of en-echelon, high-angle faults downthrown to the southeast [4,5]. Increased permeability along faults in exposed Edwards limestones allowed meteoric recharge and dissolution, forming complex west-east and southwest-northeast flowpaths within hydrologically connected segments of the aquifer [6]. Present-day flowpaths are overprinted on hypogenically-derived permeability [7]. To the south and east, freshwater in the aquifer is confined below non-karstic units and juxtaposed against a lower-permeability zone of sulfide-rich, saline water along a steep freshwater-saline water interface (FWSWI) [8]. Shallower flowpaths and less faulting dominate in the Edwards-Trinity system to the north and west of the Edwards Aquifer. This region also contains many active stream caves. 


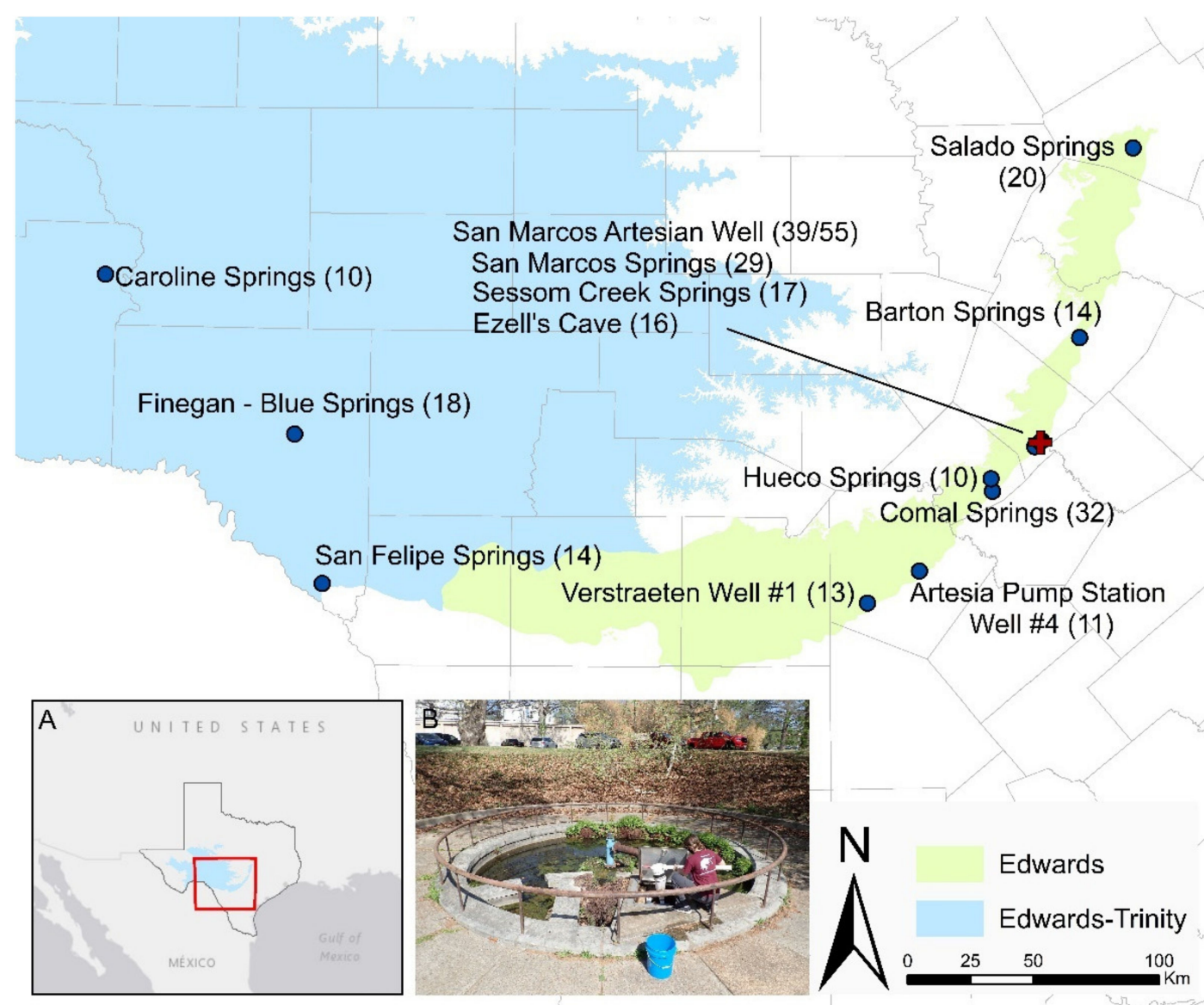

Figure 1. San Marcos Artesian Well and other diverse groundwater sites ( $>10$ stygobionts) in the Edwards and EdwardsTrinity Aquifers. Species richness in parentheses. Inset A: Overview map. Inset B: San Marcos Artesian Well. Two numbers reported for the SMAW are published records (39) used in $\beta$-diversity analyses and published + unpublished, undetermined taxa (55).

The San Marcos Artesian Well (SMAW, state well number 6701828), on the Texas State University, San Marcos campus, is a flowing freshwater artesian well completed in late 1895 or early 1896 in the confined portion of the Edwards aquifer. The well intersects a $1.5 \mathrm{~m}$ tall phreatic conduit at a depth of $-59.5 \mathrm{~m}$ [9]. Nearby saline wells illustrate proximity (i.e., $<100 \mathrm{~m}$ ) to the FWSWI. Dye tracing showed hydraulic connectivity between nearby Ezell's Cave (2.9 km to the southwest), the SMAW, and Deep Hole Spring (part of the San Marcos Springs Complex, 500 m northeast) [10]. From 2015 to 2020, discharge from the well averaged 16 L/s. During November 2013, 15-min continuous data documented average water properties of: temperature $22.3{ }^{\circ} \mathrm{C}( \pm 0.007)$, dissolved oxygen $5.3 \mathrm{mg} / \mathrm{L}( \pm 0.01)$, and electrical conductivity $608 \mu \mathrm{S} / \mathrm{cm}( \pm 0.5)$.

The SMAW and, to a lesser extent, springs, caves, and other wells in the Edwards and Edwards-Trinity Aquifers have been the focus of numerous studies ranging from taxonomic to ecological investigations. In the literature, the SMAW has been referred to as SWTSU Well, Texas State Artesian Well, and artesian well at San Marcos, and it is probably the source for most of the data for 'San Marcos Springs' in the first global list of subterranean biodiversity hotspots [11]. San Marcos Springs are hydrologically connected to the SMAW but inundated by a shallow reservoir, making them more difficult to sample. Consequently, fewer stygobionts are documented from San Marcos Springs relative to the SMAW.

The SMAW was the site of the first biospeleological investigations in Texas with the descriptions of the salamander Eurycea rathbuni (Stejneger, 1896), the shrimp Palaemon antrorum (Benedict, 1896), the isopod Cirolanides texensis (Benedict, 1896), and the amphi- 
pod Stygobromus flagellatus (Benedict, 1896). Soon after, Ulrich [12] described the isopod Lirceolus smithii (Ulrich, 1902) and two species of cyclopoid copepods. After those initial descriptions, taxonomic work in the Edwards Aquifer slowed until the late 1970s when Glenn Longley began a second phase of investigation with systematic sampling of the well via drift nets. Longley initiated important collaborations with taxonomists including John Holsinger (Amphipoda) and Robert Hershler (Gastropoda) and supported graduate students such as Henry Karnei that investigated Edwards Aquifer biodiversity. Through his collaboration and directorship of the Edwards Aquifer Research and Data Center, San Marcos, TX, USA (EARDC), created in 1979, the number of stygobionts recorded from the SMAW increased from eight to 25 between 1976 and 2000. Holsinger and Longley [9] and Longley [2] illustrated that the SMAW had a globally diverse stygobiont fauna, although previous studies had illustrated that faunal composition at the well was apparently distinct compared to other USA stygofauna sites [12-17]. Holsinger [15] and Holsinger and Longley [9] emphasized the presence of both marine and freshwater derived species at the site.

A third phase of biologic investigation began in the mid-2010s, when Benjamin Schwartz became director of the EARDC upon Longley's retirement. Schwartz also facilitated systematic sampling and taxonomic collaborations, most importantly with Okan Külköylüoğlu (Ostracoda) [18-23]. He also initiated morphometric and molecular analyses $[23,24]$ to identify new records of previously described species. Since 2015, published stygobiont richness at the SMAW has increased from 26 to 39 (Table 1).

Longley [2] hypothesized that the Edwards Aquifer foodweb is not supported by allochthonous organic matter from the surface, but rather by 'fossil' organic matter originating at depth in the saline portion of the aquifer. Longley's hypothesis foreshadowed later studies that revealed the role of chemolithoautotrophy within the aquifer. Birdwell and Engel [25] characterized microbially derived dissolved organic matter along the FWSWI with a chromophoric signature distinct from terriginous surface and soil porewaters. Gray and Engel [26] identified microbial communities along the FWSWI with taxonomic composition similar to other chemolithoautotrophic systems. Finally, Hutchins et al. [27] reported isotopic signatures of carbon that indicated that chemolithoautotrophic production, in addition to photosynthetic organic matter, supports the metazoan community at the SMAW. They also suggested that chemolithoautotrophy might facilitate reduced extinction rates during climatically unfavorable periods. Hutchins et al. [28] suggested that, as a spatially and temporally stable food source, chemolithoautotrophy might support high biological diversity by increasing resource exploitation and reducing competition. By combining stable isotope and mouthpart morphologic data, the authors illustrated trophic niche partitioning among amphipod species, making the SMAW one of a small but growing number of sites with evidence of niche partitioning among stygobionts [29-31].

Given the hydraulic and geologic complexity of the Edwards Aquifer, the SMAW likely integrates water and stygobionts from multiple flowpaths, discrete locations, and microhabitats within the aquifer. Because hydraulic conditions along any discrete flowpath vary in response to precipitation and antecedent conditions, groundwater assemblage composition at the well may vary temporally as well. Temporal dynamics in groundwater community structure have been investigated in alluvial aquifers [32], epikarst [33], and karst aquifers [34-36], although to our knowledge, studies in the latter have been limited to vadose and shallow saturated systems rather than deep, phreatic sites. In high gradient, hydraulically 'flashy' karst aquifers, studies have emphasized the role of flood pulses in the 'spatial redistribution' of species $[34,35]$ and how species-specific responses depend on hydraulic differences in microhabitats (e.g., transmissive conduits versus peripheral fracture networks). However, as Gibert et al. [34] noted, flow conditions may be more stable in the phreatic zone. Therefore, it is unclear whether stygobionts in more hydraulically stable, phreatic aquifers exhibit similar temporal variability. If so, then from a species-accumulation perspective, sample events might capture different components of 
a dynamic groundwater meta-community and species richness more likely describes the meta-community at a local, rather than site scale.

At a regional scale, the SMAW and surrounding groundwater environments are part of the larger Edwards Aquifer Groundwater Ecosystem. We use the term 'Edwards Aquifer Groundwater Ecosystem' to highlight the aquifer as a spatially extensive, discrete ecosystem with unique hydrogeologic, biological, and socio-economic elements. In contrast, conceptualizations of the aquifer have tended to emphasize isolated components of the system (i.e., groundwater as a resource, single sites as critical habitat for subsets of species). Although other sites in the aquifer have not been investigated as thoroughly as the SMAW, previous work has illustrated that diverse assemblages of stygobionts occur throughout the aquifer system [17,37]. Multiple diverse groundwater sites within a contiguous but heterogeneous aquifer system afford opportunity to investigate patterns of beta-diversity at the aquifer scale. Previous work has demonstrated that globally, most stygobionts are small-range endemics [38], and that overall diversity from local to continental scales is explained in part by the species-turnover component of beta ( $\beta$ )-diversity [39]. Although distance between sites, coupled with small ranges and limited dispersal potential [40], is a parsimonious explanation for species turnover, environmental differences among sites have also been proposed to explain differences in species richness and composition in epikarst copepod communities [41].

Here, we present a species list for the SMAW, using published and unpublished data. We also investigate temporal dynamics in community composition at the site via high-frequency sampling across 3 years and 85 samples. We hypothesized that samples from the well do not suggest a temporally stable community, but rather, show temporal variability, as in other groundwater systems. Specifically, we hypothesized that assemblage structure at the SMAW would vary seasonally and in response to precipitation-driven hydraulic changes. To our knowledge, this is the first assessment of temporal community dynamics within a deep phreatic karst system. We also investigate species richness at the SMAW within the context of the greater Edwards Aquifer Groundwater Ecosystem, highlighting other diverse sites. We assess whether (1) regional-scale patterns of $\beta$-diversity are explained by species turnover (replacement) or regional/ site-based differences in species richness and (2) whether those dissimilarities are explained by distance or site-type (i.e., springs versus wells and caves). We predicted that species turnover rather than differences in species richness drive $\beta$-diversity patterns, and that species turnover would be affected by distance rather than site type.

\section{Materials and Methods}

\subsection{SMAW Diversity and Temporal Dynamics}

We conducted a literature review to compile a stygobiont species list for the SMAW. In a few instances, taxonomic experts were consulted to determine whether species should be considered stygobionts (as defined by Trajano and de Carvalho [42]). Unpublished, undescribed taxa were also included, based on communication with collaborators and personal observations in the authors' taxonomic area of expertise. For temporal analysis, 85 samples were collected via $60 \mu \mathrm{m}$ drift nets attached to the outflow of the well for between 24 and $72 \mathrm{~h}$ between 13 February 2013 and 20 November 2015 (Table S1). Samples were preserved in $95 \% \mathrm{EtOH}$ and sorted at $10 \times$ magnification. Species were identified to the lowest taxonomic level by the authors or taxonomic experts (see acknowledgements) although some undescribed taxa were lumped as a single taxon (e.g., Microcerberidae, Trombidiformes). Voucher specimens for most taxa are retained in the Aquifer Biodiversity Collection of the EARDC, Texas State University, San Marcos, TX, USA.

Statistical tools in R v4.0.3 were applied to explore stygobiont time-series data from the SMAW. A Ward's minimum variance dendrogram based on species abundances was created using the vegan package following the method of Borcard et al. [43]. A graph of silhouette widths was visually examined to estimate the optimal number of clusters, which was statistically assessed via analysis of similarity using a Bray-Curtis similarity 
matrix and 9999 permutations. Species associated with each group at $p<0.05$ were identified using Indicator Species Analysis run with 999 permutations.

To disentangle the potential effects of discharge, season, and unexplained temporal influences on community composition, redundancy analysis was performed using the vegan package. Independent variables included season, discharge, and distance-based Moran's eigenvector maps (dbMEM) derived from time (day) since the first sampling event $\left(\mathrm{T}_{0}\right)$ (Table $\left.\mathrm{S} 1\right)$. Season was coded as a categorical variable according to Kollaus and Bonner [44]: winter = December-February, spring = March-May, summer = June-August, fall = September-November. Discharge data were derived from mean daily discharge recorded by the U.S. Geological Survey at the San Marcos River gaging station USGS 08170500 [45], converted to liters per second. The gaging station is approximately $0.5 \mathrm{~km}$ downstream from the San Marcos Springs, and discharge at the station is a surrogate for local aquifer levels, which are correlated with average flow velocities in the Edwards Aquifer [46]. Distance-based Moran's eigenvector maps (dbMEMs) were created using the method of Legendre and Gauthier [47] as implemented using the dbmem function in the adespatial package. dbMEMs were derived from a distance matrix of the number of days between sampling events and represent a spectral decomposition of the temporal relationships among samples [47]. Significance of dbMEMs was assessed using the moran.randtest function in the adespatial package, and only dbMEMs significant at $p<0.05$ were used in the RDA. Periodicity of significant dbMEMs was not calculated because of many missing values over the sampling period. RDAs on discharge and season only, and on the dbMEMs only, were performed prior to a global RDA with both sets of independent variables and variance partitioning. The species data matrix was Hellinger transformed and singletons and doubletons were removed, but data were not detrended prior to analysis. Significance of RDAs, independent variables, and canonical axes was assessed using the anova.cca function in vegan, with 1000 permutations. Variance explained by discharge and season versus dbMEMs was assessed using the varpart function in vegan.

\subsection{Edwards Aquifer Groundwater Ecosystem $\beta$-Diversity}

To place the SMAW community within the broader context of the Edwards Aquifer Groundwater Ecosystem, distance-based RDA (dbRDA) was performed to assess the influence of distance, aquifer pool, and site type on $\beta$-diversity in R v.4.0.3. A literature review identified additional Edwards Aquifer and Edwards-Trinity Aquifer sites with high diversity (with an arbitrary cut-off of 10 or more stygobiont species). Primary and grey literature resources and previously unreported records of described species represented by specimens in the collections of the author and colleagues were included (Table S2). Unpublished, undetermined taxa were not included. $\beta$-diversity (Jaccard index total dissimilarity) was estimated and partitioned into two components (replacement, richness) using the beta function in the package BAT [48]. Linear trends in $\beta$-diversity measures were assessed using linear regression against log-transformed Euclidean geographic distance between sites, with Bonferroni correction applied for multiple comparisons. Dissimilarity matrices were used as the response variable in dbRDA. Predictor variables included site type (spring or well/cave), aquifer pool, and a distance-based Moran's eigenvector map (dbMem) derived from site coordinates (UTM). Because of high multicolinearity (VIF > 10) between aquifer pool and dbMem variables, aquifer pool was removed prior to analysis. The single dbMem derived from the coordinates of the 13 assessed sites was calculated using the dbmem function in the adespatial package. Because sites are unevenly spaced and often widely distributed, the truncation threshold was set at $217039.8 \mathrm{~m}$, limiting assessment of spatial structure to broad spatial scales. dbRDAs were conducted using the capscale function in the vegan package. Significance of the dbRDA and predictor terms was assessed via the anova.cca function in vegan, with 1000 replications. 


\section{Results}

\subsection{SMAW Diversity and Temporal Dynamics}

Currently, 55 taxa have been documented from the SMAW, including 39 species recorded in literature (Table 1), two of which remain undescribed (Parabogidiella sp. Holsinger, 1980 and Erpobdella sp.). An additional 16 stygobiont taxa (2 described species and 14 undetermined taxa) are reported here for the first time (Table 1). Crustaceans dominate the SMAW fauna, comprising $75 \%$ of documented species. These include the only thermosbaenacean in the United States [49] and a globally significant amphipod fauna [9] of 12 species in five families. Additionally, 11 ostracod and nine isopod species occur at the site. Unique soft-bodied taxa include the only North American stygobitic leech [50], two vertebrate parasites (see below), and five species in the gastropod genus Phreatodrobia. The beetle, Haideoporus texanus (Young and Longley, 1976) is one of five species of stygobitic dytiscid beetles in the United States (four of which are associated with the Edward Aquifer [51]). A single vertebrate, the Texas blind salamander, E. rathbuni, occurs at the well. The SMAW is the type locality for 25 of the published taxa $(64 \%)$, and eight of these (21\%) are single-site endemics (Table 1). New SMAW site records, (including species descriptions and new records for described species) have accumulated unevenly over time (Figure 2).

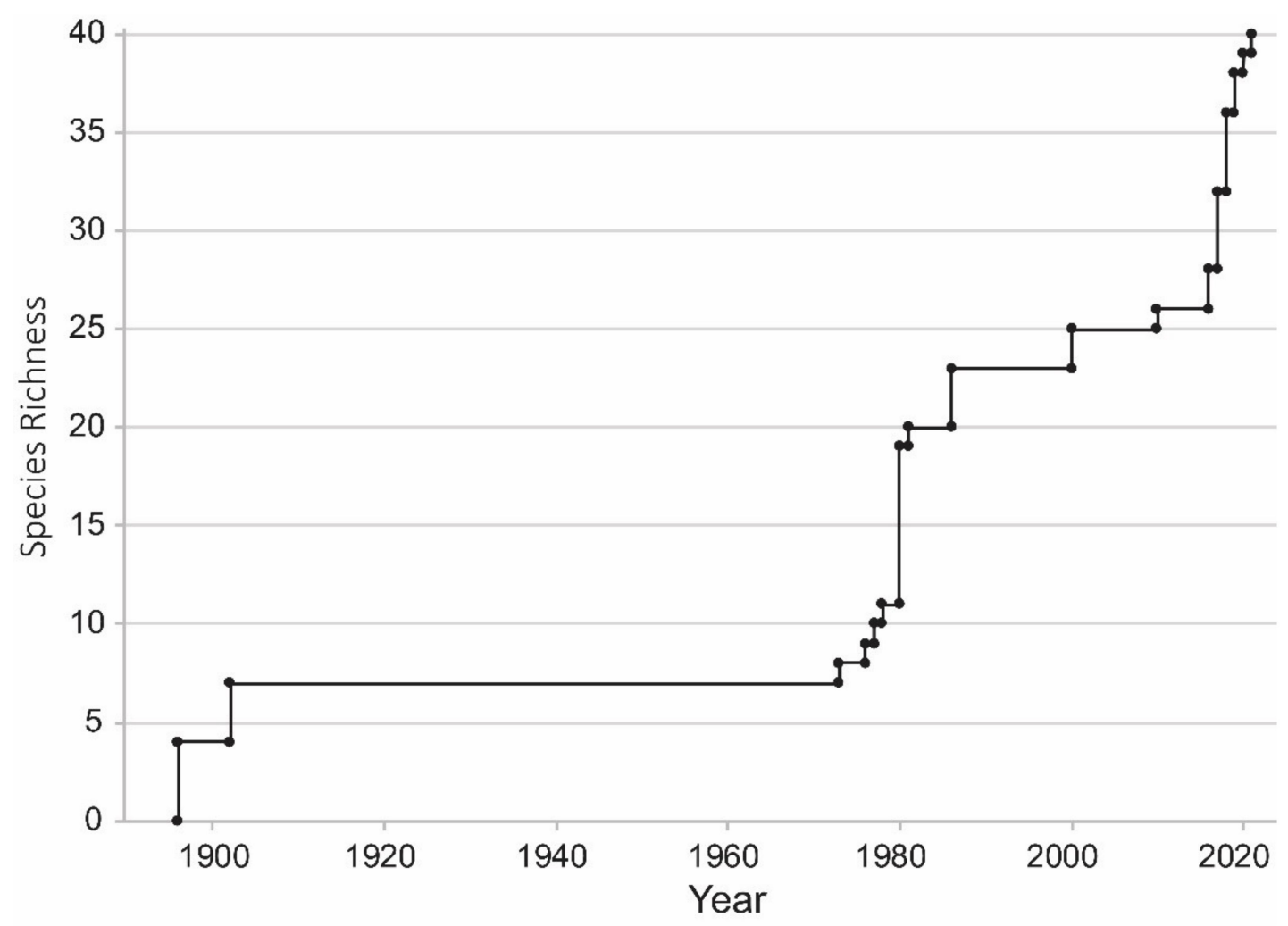

Figure 2. Published species richness at the San Marcos Artesian Well over time. Undetermined, unpublished taxa excluded. 
Table 1. Stygobionts from the San Marcos Artesian Well and basis of record. $\S=$ single site endemic; $\dagger=$ type locality.

\begin{tabular}{|c|c|c|c|c|c|}
\hline Phylum & Class & Order & Family & Species & Reference \\
\hline Nematoda & Enoplea & Trichocephalida & Capillariidae & Amphibiocapillaria texensis Moravec and Huffman, $2000^{\dagger}$ & [52] \\
\hline Acanthocephala & Eoacanthocephala & Neoechinorhynchida & Dendronucleatidae & Dendronucleata americana Moravec and Huffman, $2000^{+\S}$ & [52] \\
\hline Platyhelminthes & Rhabditophora & Tricladida & Kenkiidae & Sphalloplana mohri Hyman, 1938 & [53] \\
\hline \multirow[t]{2}{*}{ Annelida } & \multirow[t]{2}{*}{ Clitellata } & Arhynchobdellida & Erpobdellidae & Erpobdella sp. & [2] \\
\hline & & Lumbriculida & Lumbriculidae & gen. sp. undet. & Steve Fend, pers. comm. \\
\hline Mollusca & Gastropoda & Littorinimorpha & Cochliopidae & $\begin{array}{l}\text { Phreatodrobia micra (Pilsbry and Ferriss, 1906) } \\
\text { Phreatodrobia nugax (Pilsbry and Ferriss, 1906) } \\
\text { Phreatodrobia plana Hershler and Longley, 1986 } \\
\text { Phreatodrobia rotunda Hershler and Longley, } 1986\end{array}$ & $\begin{array}{l}{[54]} \\
{[55]} \\
{[55]} \\
{[55]}\end{array}$ \\
\hline \multirow[t]{7}{*}{ Arthropoda } & \multirow[t]{2}{*}{ Ostracoda } & \multirow[t]{2}{*}{ Podocopida } & Candonidae & $\begin{array}{c}\text { Cabralcandona mixoni Külköylüoğlu, Yavuzatmaca, Akdemir, } \\
\text { Schwartz and Hutchins, } 2019^{\dagger \S} \\
\text { Candonopsis sp. } \\
\text { Comalcandona sp. } \\
\text { Cypria lacrima Külköylüoğlu, Akdemir, Yavuzatmaca, Schwartz } \\
\text { and Hutchins, } 2017^{\dagger \S} \\
\text { Lacrimacandona wisei Külköylüoğlu, Yavuzatmaca, Akdemir, } \\
\text { Schwartz and Hutchins, } 2017^{+\S} \\
\text { Namiotkocypria haysensis Külköylüoğlu, } 2018^{\dagger \S} \\
\text { Rugosuscandona scharfi Külköylüoğlu, Akdemir, Yavuzatmaca, } \\
\text { Schwartz and Hutchins, } 2017^{\dagger} \\
\text { Ufocandona hannaleeae Külköylüoğlu, Yavuzatmaca, Akdemir, } \\
\text { Schwartz and Hutchins, } 2017^{\dagger} \$ \\
\text { Schornikovcandona bellensis Külköylüoğlu, Yavuzatmaca, } \\
\text { Akdemir, Diaz and Gibson, } 2017\end{array}$ & $\begin{array}{l}{[18]} \\
\text { Okan Külköylüoğlu pers. comm. } \\
\text { Okan Külköylüoğlu pers. comm. } \\
{[19]} \\
{[20]} \\
{[56]} \\
{[21]} \\
{[22]} \\
\text { Okan Külköylüoğlu pers. comm. }\end{array}$ \\
\hline & & & Darwinulidae & $\begin{array}{l}\text { Darwinula sp. } \\
\text { Vestalenula sp. }\end{array}$ & $\begin{array}{l}\text { Okan Külköylüoğlu pers. comm. } \\
\text { Okan Külköylüoğlu pers. comm. }\end{array}$ \\
\hline & \multirow[t]{2}{*}{ Hexanauplia } & Cyclopoida & Cyclopidae & $\begin{array}{l}\text { Cyclops cavernarum Ulrich, } 1902^{+\S} \\
\text { Cyclops learii Ulrich, } 1902^{+\S}\end{array}$ & $\begin{array}{l}{[12]} \\
{[12]}\end{array}$ \\
\hline & & Harpacticoida & & gen. sp. undet. & Diego Figueroa, pers. comm. \\
\hline & \multirow[t]{3}{*}{ Malacostraca } & Bathynellacea & Bathynellidae & $\begin{array}{l}\text { Hobbsinella edwardensis Camacho, Hutchins, Schwartz, Dorda, } \\
\text { Casado and Rey, } 2017^{\dagger}\end{array}$ & [57] \\
\hline & & Thermosbaenacea & Monodellidae & Tethysbaena texana (Maguire, 1965) & [17] \\
\hline & & Isopoda & Microcerberidae & $\begin{array}{l}\text { Microcerberidae sp. } 1 \\
\text { Microcerberidae sp. } 2\end{array}$ & $\begin{array}{c}{[58]} \\
\text { pers. obs. }\end{array}$ \\
\hline
\end{tabular}


Table 1. Cont.

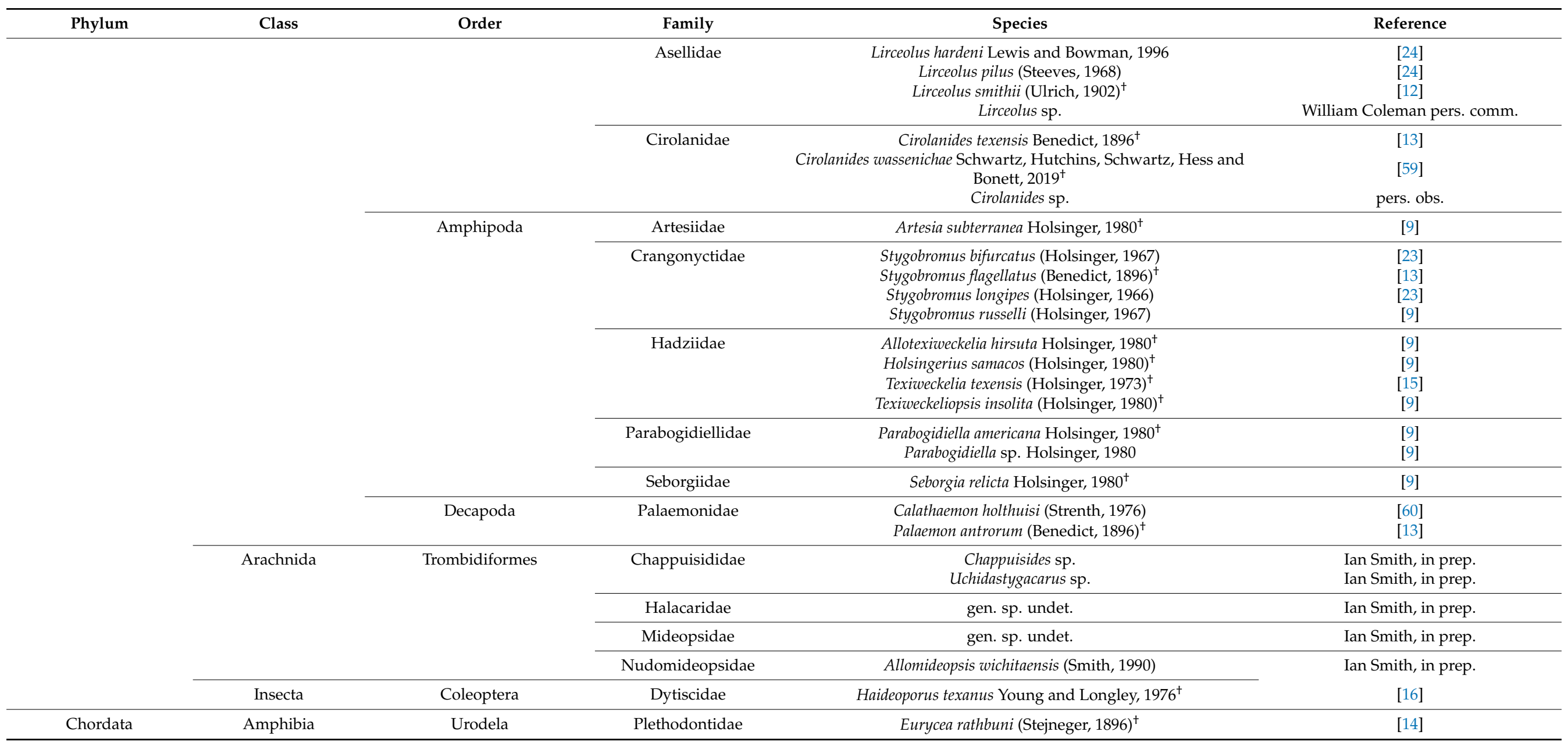


The stygobiont community at the SMAW is characterized by some taxonomic and ecological uncertainty. In addition to the two undescribed species already mentioned, the two copepod species reported from the well are poorly described and have been designated as nomen inquirendum or nomen dubium by some [61]. Two species, the nematode Amphibiocapillaria texensis Moravec and Huffman, 2000 and the acanthocephalan Dendronucleata americana Moravec and Huffman, 2000 are parasites of the salamander E. rathbuni. Both parasites complete their life cycles using stygobiont invertebrates and should be considered stygobionts (David Huffman, pers. comm.). Neither parasite species have been conclusively collected from the epigean salamander Eurycea nana Bishop, 1941, which occurs in the San Marcos Springs and San Marcos River.

Eighty-five samples collected between 2013 and 2015 contained 42,814 individuals with an average of 275 individuals and 15 taxa per $24 \mathrm{~h}$ period (Table S1). Incidental epigean taxa were removed prior to temporal analysis $(n=61)$. Undetermined individuals $(n=87)$, mostly ostracods, were also removed because they could not be confidently assigned a taxonomic identity. An additional 415 juvenile and damaged individuals were assigned to taxa present in the sample.

Log-transformed total abundances show a nearly normal distribution (Figure 3), and only two species in the 85 samples (Lirceolus pilus (Steeves, 1968) and an unidentified nematode) were found in only one or two samples, suggesting that rare species are mostly accounted for by the sampling effort. Three species (Phreatodrobia micra (Pilsbry and Ferriss, 1906), Lirceolus hardeni Lewis and Bowman, 1996, and Stygobromus bifurcatus (Holsinger, 1967)) are known from the site by single specimens but were not present in any of the 85 analyzed samples. The two parasitic taxa present in the aquifer were not detected in our sampling strategy, which did not involve dissection. Additionally, copepods and mites were not identified to species, so all copepods and mites were each lumped into a single category. A histogram of the number of samples in which taxa occur shows a bimodal distribution, suggesting that most species are either common or rare (Figure 3). The shrimp, P. antrorum, makes up 44\% of individuals, and just four taxa: P. antrorum, Copepoda, Cypria lacrima Külköylüoğlu, Akdemir, Yavuzatmaca, Schwartz and Hutchins, 2017, and Texiweckeliopsis insolita (Holsinger, 1980) make up over $90 \%$ of individuals. The 23 most infrequent taxa (61\% of all taxa) collectively make up less than $1 \%$ of the total number of individuals.
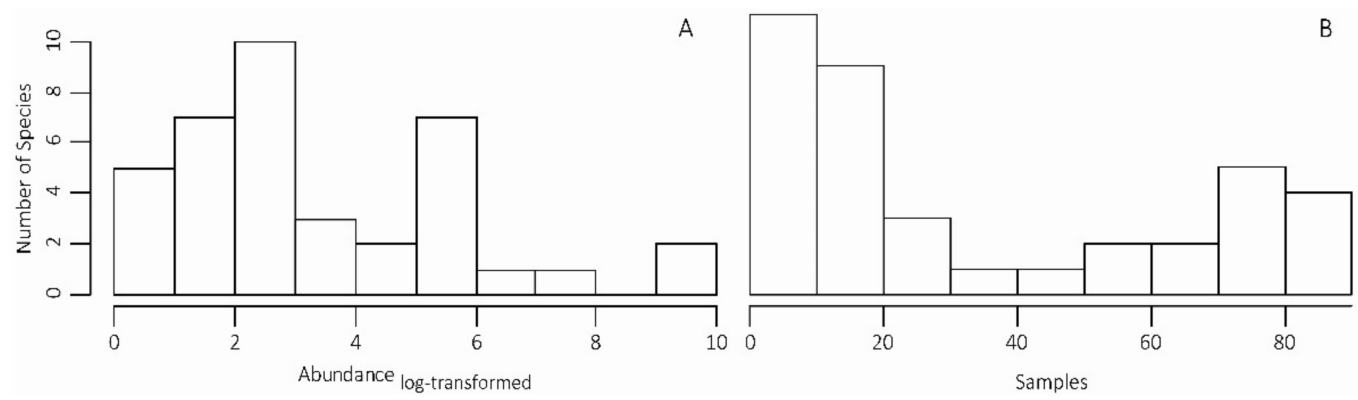

Figure 3. Histograms of (A) log-transformed species abundance and (B) frequency of species occurrences in high-frequency samples from the San Marcos Artesian Well.

Samples form significant clusters based on species abundances (Figure 4). Two clusters produced an optimal silhouette width, but between two and five clusters had similarly high silhouette widths. ANOSIM confirmed that groupings of samples into five and two clusters were both significant ( $\mathrm{R}: 0.45$ and $p<0.001 ; \mathrm{R}=0.26$ and $p<0.001$, respectively). Several taxa were significantly associated $(p<0.05)$ with one or two clusters although some species were associated with two clusters that were not nearest neighbors (i.e., species could be associated with two clusters that were otherwise compositionally dissimilar to one another). 


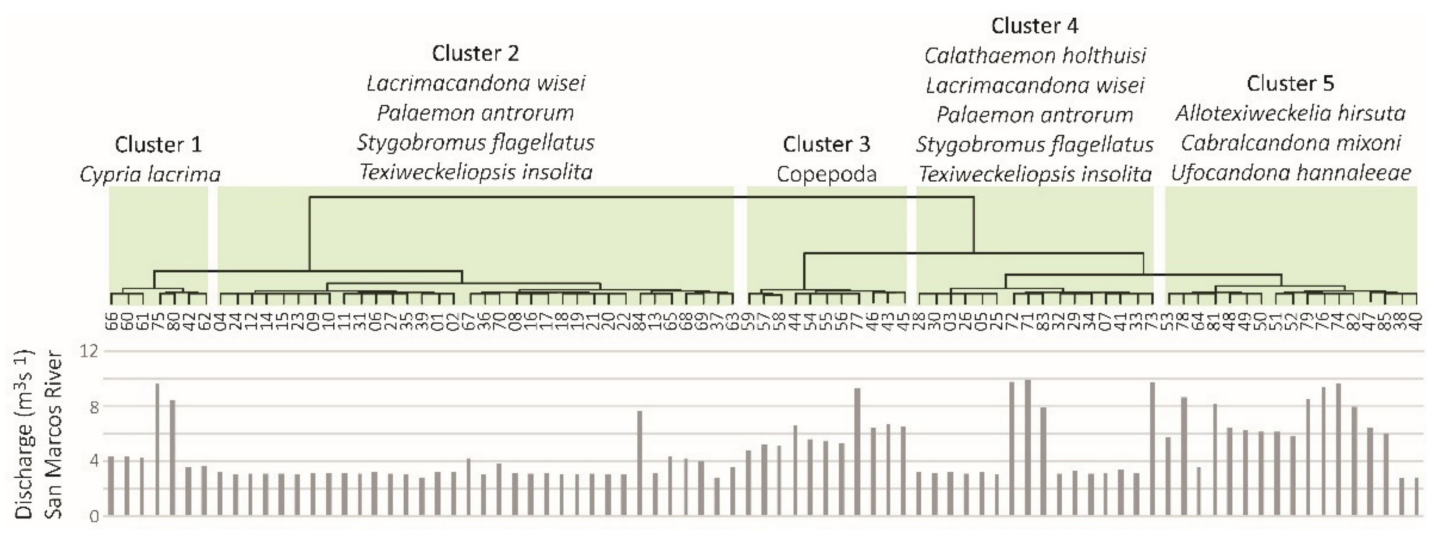

Figure 4. Ward's minimum variance dendrogram of high-frequency sample stygobiont community data from the San Marcos Artesian Well, with corresponding discharge from the nearby San Marcos River. Sample numbers (dendrogram tips) refer to sample order (e.g., 01 occurred at $\mathrm{T}_{0}$, followed by 02 ) but time between consecutive samples is variable. Significant groupings are demarcated by shading, and significantly associated taxa are shown above. Discharge is not represented by a hydrograph because samples are clustered by community similarity and are not shown in chronological order.

Although there was a significant temporal trend in the community data $(p<0.05)$, only a small proportion of variance was constrained by sampling date alone. Separate redundancy analyses (RDA) using only discharge plus season and only distance-based Moran's eigenvector maps (dbMEMs) were both significant $(\mathrm{F}=8.589, p=0.001 ; \mathrm{F}=3.930$, $p=0.001$, respectively). A global RDA incorporating discharge, season, and dbMEMs was also significant $(\mathrm{F}=9.274, p=0.001)$. Variance partitioning between discharge plus season versus dbMEMs showed that shared explained variance was not significant. Discharge and season explained $32 \%$ of variance in community structure, and both variables were significant at $p=0.001(\mathrm{~F}=21.084$ and 8.013 , respectively). dbMEMs explained $18 \%$ of variance in community structure, and three of four dbMEMs were significant at $p=0.001$ $(\mathrm{F}=6.635-10.878)$. The first three axes of the global RDA were significant at $p=0.001$ and cumulatively accounted for $45 \%$ of the total explained variance. The first axis illustrated a gradient between low-flow samples (primarily during spring and summer) with larger numbers of the shrimp P. antrorum and the amphipod T. insolita and high-flow samples (primarily during fall and winter) with higher numbers of copepods, the snail Phreatodrobia plana Hershler and Longley, 1986, and the amphipod Texiweckelia texensis (Holsinger, 1980) (Figure 5). The second axis illustrated unexplained temporal gradients (dbMEM1 and dbMEM3) between samples (primarily in the summer) with higher numbers of the ostracod C. lacrima and samples with higher numbers of the amphipods S. flagellatus and Seborgia relicta Holsinger, 1980 (Figure 5). Clustering of sites in RDA space (influenced by community composition and environmental variables) reflects clustering on the Ward's minimum variance dendrogram (based only on community composition, Figure 4). 


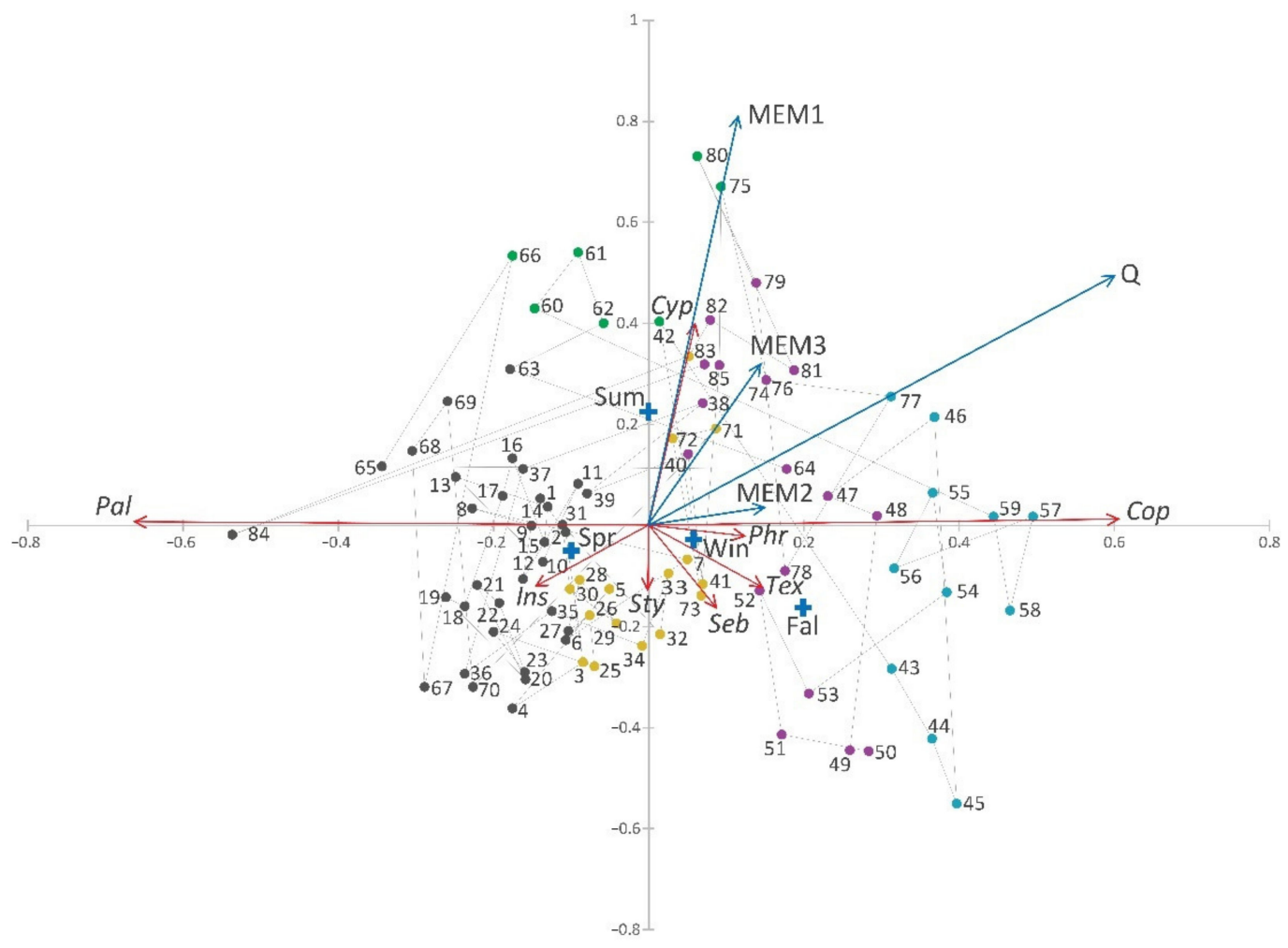

Figure 5. First two axes of global Redundancy Analysis for stygobionts from high-frequency sampling at the San Marcos Artesian Well. Sample numbers refer to sample order (e.g., 01 occurred at $\mathrm{T}_{0}$, followed by 02 ) but time between consecutive samples is variable. Sample colors refer to Ward's minimum variance clustering (Figure 3): green = cluster 1, black = cluster 2, light blue $=$ cluster 3 , yellow $=$ cluster 4 , and purple $=$ cluster 5 . Faint lines connect consecutive samples. For clarity, only taxa with the highest loadings on axes 1 and 2 are shown (red arrows): Cyp = Cypria lacrima, Phr = Phreatodrobia plana, Tex = Texiweckelia texensis, Seb = Seborgia relicta, Sty = Stygobromus flagellatus, Ins = Texiweckeliopsis insolita, and Pal = Palaemon antrorum. Blue arrows show biplot scores for constraining variables: $Q=$ discharge, MEM1-MEM3 represent significant Moran's eigenvector maps describing temporal relationships among samples at different scales. Blue pluses are centroids for categorical seasons: Sum = summer, Spr = spring, Win = winter, and Fal = fall.

\subsection{Edwards Aquifer Groundwater Ecosystem $\beta$-Diversity}

Thirteen sites with 10 or more stygobionts were identified across the Edwards and Edwards-Trinity Aquifers (Figure 1, Table S2). Sites included three flowing artesian wells, one cave, and nine springs varying from 1st magnitude springs (e.g., Comal Springs) to a small, intermittent spring (Sessom Creek Spring). All sites are hydraulically connected to the phreatic zone of the Edwards or Edwards-Trinity Aquifers. Total dissimilarity and replacement increased with increasing distance $\left(R^{2}=0.57\right.$ and 0.32 , respectively) at $p<0.001$. Differences in species richness did not exhibit a spatial trend. dbRDA revealed significant site-type and distance-based effects on total dissimilarity $(\mathrm{F}=2.49, p=0.001$, $\left.\mathrm{R}^{2}=0.20\right)$ and replacement $\left(\mathrm{F}=2.95, p=0.001, \mathrm{R}^{2}=0.41\right)$, but not on differences in species richness. Thirty-three percent of variance in total dissimilarity was constrained by the two canonical axes (axis 1: $19 \%$, axis 2: $14 \%$ ), and both site type ( $\mathrm{F}=2.14, p=0.008$, loadings: axis $1=0.15$, axis $2=-0.99)$ and dbMem $(\mathrm{F}=2.84, p=0.001$, loadings: axis $1=0.89$, axis $2=0.46$ ) were significant terms. Thirty-seven percent of variance in replacement was constrained by the two canonical axes (axis 1: $22 \%$, axis $2: 15 \%$ ), and both site type $(\mathrm{F}=2.47, p=0.003$, loadings: axis $1=0.09$, axis $2=-1.00)$ and dbMem $(\mathrm{F}=3.43, p=0.001$, loadings: axis $1=0.91$, axis $2=0.41$ ) were significant terms. For each RDA, the first axis describes differences in dissimilarity explained by distance between sites and the second axis describes differences in dissimilarity explained by site type (Figure 6). 

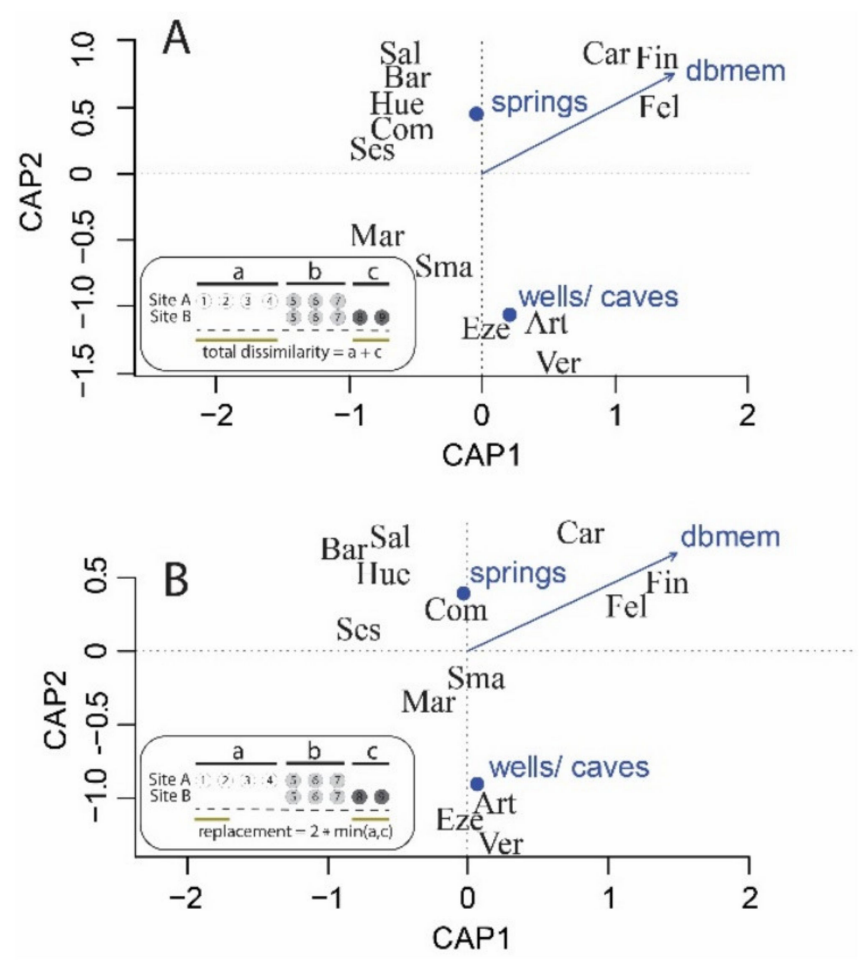

Figure 6. First two axes (canonical principal coordinates) of distance-based Redundancy Analysis of total dissimilarity (A) and species replacement (B) at diverse ( $>10$ stygobionts) Edwards and Edward-Trinity Aquifer sites. Blue circles are centroids for site types. dbmem is a distance-based Moran's eigenvector map derived from latitude and longitude (UTM) of sites. Sal = Salado Springs, Bar = Barton Springs, Sma = San Marcos Artesian Well, Mar = San Marcos Springs, Ses = Sessom Creek Springs, Eze = Ezell's Cave, Hue $=$ Hueco Springs, Com = Comal Springs, Art = Artesia Pump Station Well \#4, Ver = Verstraeten Well \#1, Fel = San Felipe Springs, Fin = Finegan-Blue Springs, and Car = Caroline Springs. Insets are graphical representations of total dissimilarity and dissimilarity due to replacement, where numbers represent species (modified from Carvalho et al. [62]).

\section{Discussion}

Despite over one century of intensive sampling and study, knowledge of diversity at the SMAW remains incomplete. 'Orphan' taxa (e.g., Cyclopoida and Harpacticoida) are completely or largely unassessed. Even in better-studied groups (e.g., Isopoda), undescribed taxa have been identified. We conclude that reported species richness is underestimated. The continuing increase in species recorded at the site over time (Figure 2) and the near absence of taxa that are important elements of many groundwater communities (e.g., Copepoda) supports this assertion. The semi-normal distribution of species abundances in high-frequency samples (Figure 3A) and species accumulation curves (data not shown) suggest that sampling has been adequate for known species. Additional species discovery at the well will mostly likely result from additional taxonomic assessment of the orphan taxa discussed above, and cryptic species [23,24]. Nevertheless, with 55 groundwater-obligate taxa (Table 1), the SMAW is the most diverse groundwater site in North America and among the most diverse sites globally [63]. Proposed explanations for high-biodiversity within the Edwards Aquifer Groundwater Ecosystem include the role of marine embayments producing relic taxa (i.e., a richer colonist pool sensu Cardinale et al. [64]) [9] and high rates of primary productivity [27] supported, in part, by chemolithoautotrophy. Long-term productive energy, which is linked to climate and climatic-variability, has emerged as an important driver of groundwater diversity patterns in Europe and North America [65,66]. South of Pleistocene ice sheets and permafrost, Central Texas climate was cooler and wetter during glacial periods [67], potentially having a positive effect on productivity in the region. The region has become warmer and dryer since the last glacial maximum and 
although pronounced aridity during the mid-Holocene Altithermal Period would have reduced surface productivity, Hutchins et al. [27] hypothesized that chemolithoautotrophic production may have mitigated effects of aridity-related changes in surface productivity on stygobionts. In Europe, habitat heterogeneity is also an important predictor of stygobiont richness at mid and southern latitudes [65] and may be important in the hydrogeologically complex Edwards Aquifer.

To our knowledge, our analysis of a high-frequency dataset spanning multiple seasons and flow regimes provides the first illustration of temporal variability in a deep phreatic aquifer community. Community composition-based clustering of samples suggests that some species abundances vary in synchrony over time, which would not be expected in random samples from a temporally stable community. The bimodal distribution of taxa frequencies in repeated samples (Figure 3B) is interesting and may reflect the presence of two or more metacommunities: one comprised of species that are ubiquitous in flowpaths intersected by the well (e.g., Lacrimacandona wisei Külköylüoğlu, Yavuzatmaca, Akdemir, Schwartz and Hutchins, 2017, P. antrorum, S. flagellatus, T. insolita), and one or more communities comprised of species in more remote habitats that are only infrequently washed out, typically during high flows. Alternatively, the distribution may not reflect spatial or temporal heterogeneity in community structure, but rather, biological differences (e.g., benthic versus pelagic habitat, or swimming ability) in species' propensity to be expelled from the well, which would also produce a relationship between flow and sample composition.

Redundancy analysis illustrates that, like other groundwater systems, hydrologic regime plays an important role in structuring the SMAW stygobiont assemblage over time. Discharge was the most important predictor in the global RDA. The influence of discharge is also apparent when viewed alongside the community-based dendrogram (Figure 4), although several low-flow samples fall within otherwise high-flow clusters and vice versa. Samples 71 and 72 were high-flow samples collected immediately after an extended period of low-flow, and so may represent a 'piston-effect' in which rapid recharge by meteoric water pushes resident groundwater (and associated fauna) through the system [38]. Conversely, the low-flow samples 38, 40, and 83 all contained uncommon species. Since species richness at the SMAW is positively correlated with discharge (data not shown), uncommon species more strongly effect overall community composition in otherwise less-diverse, low-flow samples, and probably drive the clustering of these samples with more-diverse, high-flow samples. Sample 84, a high-flow sample clustering with low-flow samples, had a near absence of copepods, potentially reflecting an undetected sample processing error.

Why certain species appear to be associated with low or high flows is unclear. Gibert et al. [34] suggested that stygobionts are heterogeneously distributed across distinct microhabitats in aquifers, and flood pulses initiate transport of organisms in transmissive zones through the karst system. However, other direct and indirect mechanisms may also facilitate assemblage structure changes through demographic shifts or passive or active movement of species (Table 2). Analysis of hydrographs, geochemical dynamics, morphologic/ trophic patterns, and population dynamics within groups of concordant taxa may provide additional insight into causal relationship between hydrologic variability and stygobiont community dynamics. 
Table 2. Potential mechanisms by which hydraulic changes affect stygobiont assemblage composition in deep phreatic aquifers.

\begin{tabular}{|c|c|c|c|c|c|c|}
\hline & \multicolumn{3}{|c|}{ Positive Association } & \multicolumn{3}{|c|}{ Negative Association } \\
\hline & $\begin{array}{c}\text { Hydraulic/ } \\
\text { environmental effect }\end{array}$ & $\rightarrow$ & Community response & $\begin{array}{c}\text { Hydraulic/ } \\
\text { environmental effect }\end{array}$ & $\rightarrow$ & Community response \\
\hline \multirow{4}{*}{ 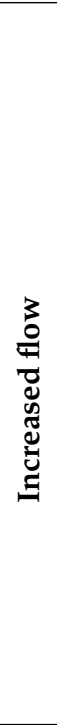 } & $\begin{array}{l}\text { Activates intermittent/ } \\
\text { alternative flowpaths } \\
\text { and hydraulic } \\
\text { connections }\end{array}$ & $\rightarrow$ & $\begin{array}{l}\text { Animals transported } \\
\text { from typically } \\
\text { less-connected aquifer } \\
\text { areas to sampling } \\
\text { location }\end{array}$ & \multirow{2}{*}{$\begin{array}{l}\text { Increased flow within } \\
\text { conduit }\end{array}$} & \multirow[t]{2}{*}{$\rightarrow$} & \multirow{2}{*}{$\begin{array}{l}\text { Animals within conduit } \\
\text { seek refuge in adjacent } \\
\text { fracture network }\end{array}$} \\
\hline & $\begin{array}{l}\text { Increased hydraulic } \\
\text { gradient from fracture } \\
\text { network to conduit } \\
\text { network }\end{array}$ & $\rightarrow$ & $\begin{array}{c}\text { Animals transported to } \\
\text { sampling location from } \\
\text { adjacent fracture } \\
\text { network }\end{array}$ & & & \\
\hline & $\begin{array}{l}\text { Increased sediment } \\
\text { transport and conduit } \\
\text { boundary velocities }\end{array}$ & $\rightarrow$ & $\begin{array}{c}\text { Dislodges benthic/ } \\
\text { interstitial organisms } \\
\text { already within sampling } \\
\text { area }\end{array}$ & \multirow{2}{*}{$\begin{array}{l}\text { Changes in nutrient } \\
\text { availability, community } \\
\text { composition, } \\
\text { and geochemistry }\end{array}$} & \multirow[b]{2}{*}{$\rightarrow$} & \multirow{2}{*}{$\begin{array}{l}\text { Direct and indirect } \\
\text { demographic (e.g., } \\
\text { reproduction) or species } \\
\text { interaction (e.g., ecologic } \\
\text { release) effects }\end{array}$} \\
\hline & $\begin{array}{l}\text { Changes in nutrient } \\
\text { availability, community } \\
\text { composition, } \\
\text { and geochemistry }\end{array}$ & $\rightarrow$ & $\begin{array}{c}\text { Direct and indirect } \\
\text { demographic (e.g., } \\
\text { reproduction) or species } \\
\text { interaction (e.g., ecologic } \\
\text { release) effects }\end{array}$ & & & \\
\hline \multirow{2}{*}{ 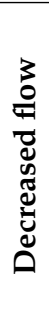 } & $\begin{array}{l}\text { Decreased flow within } \\
\text { conduit }\end{array}$ & $\rightarrow$ & $\begin{array}{c}\text { Animals within fracture } \\
\text { network move into } \\
\text { conduit }\end{array}$ & \multirow{2}{*}{$\begin{array}{l}\text { Changes in nutrient } \\
\text { availability, community } \\
\text { composition, } \\
\text { and geochemistry }\end{array}$} & \multirow[b]{2}{*}{$\rightarrow$} & \multirow{2}{*}{$\begin{array}{l}\text { Direct and indirect } \\
\text { demographic (e.g., } \\
\text { reproduction) or species } \\
\text { interaction (e.g., ecologic } \\
\text { release) effects }\end{array}$} \\
\hline & $\begin{array}{l}\text { Changes in nutrient } \\
\text { availability, community } \\
\text { composition, } \\
\text { and geochemistry }\end{array}$ & $\rightarrow$ & $\begin{array}{c}\text { Direct and indirect } \\
\text { demographic (e.g., } \\
\text { reproduction) or species } \\
\text { interaction (e.g., ecologic } \\
\text { release) effects }\end{array}$ & & & \\
\hline
\end{tabular}

As Gibert et al. [34] also acknowledged, groundwater flow alone does not explain temporal dynamics of groundwater communities. The significant contribution of temporal dbMEMs in our RDA demonstrates unexplained temporal dynamics in community composition at multiple scales. We did not attempt to correlate dbMEMs with potential explanatory phenomenon because we did not have a priori predictions about potential mechanisms, and because our dataset did not span multi-year cyclical weather oscillations like the Atlantic Multi-decadal Oscillation or El Niño-Southern Oscillation.

The 55 taxa from the SMAW represent about half of the approximately 102 stygobionts recorded from the Edwards Aquifer, and most occur at other sites. Within an extensive aquifer, assessment of biodiversity at local to regional scales, rather than at single sites, makes more sense ecologically and for aquifer management. Cardoso et al. [48] discuss issues with analyses of $\beta$-diversity based on incomplete/uneven sampling, including underestimation of similarity. However, assessment of randomized accumulation curves to control for sample effort (sensu Cardoso et al. [68]) was not possible in this study because species lists for sites other than the SMAW were based on literature and not samples. Consequently, $\beta$-diversity data are interpreted with the acknowledgement that uneven sampling effort across sites (and across taxa) obscures patterns. Given that caveat, we did observe increasing dissimilarity and replacement with increasing distance between sites, as predicted, and total dissimilarity and replacement was greater between springs and wells/caves than within site types (although the number of diverse wells and caves was limited in number and spatial extent compared to springs). However, biplot scores showed that for both total dissimilarity and replacement, distance between sites was more important than site type. Dissimilarity among habitat types was also a relatively unimportant component of $\beta$-diversity in European stygobionts [69]. Importantly, the species richness 
difference component of dissimilarity did not vary by distance or site type, suggesting the lack of 'hotspot' regions within the Edwards Aquifer with respect to location or site type, despite uneven sampling effort across regions. Because of uneven site distribution across the aquifer, however, fine-scale patterns may be obscured. For example, Hutchins et al. [27] detected a positive relationship between species richness and proximity to the FWSWI, although biodiverse sites far from the FWSWI (e.g., Caroline and Finegan-Blue Springs) raise questions about the importance of that relationship. Certainly, species richness at fine scales varies in response to hydraulic and geochemical properties, as evidenced by lowand high-diversity sites in close proximity to one another (pers. obs.).

Relative to other groundwater habitats, knowledge of stygobiont diversity in deep phreatic karst aquifers is lacking. The SMAW and the Edwards Aquifer Groundwater Ecosystem illustrates that springs and wells can be particularly productive sites for sampling these habitats, and we suspect that biodiversity within the aquifer is not anomalous relative to other deep phreatic karst aquifers on a global scale. Although spatial biodiversity patterns have received a good deal of attention from groundwater ecologists, increasingly sophisticated analytical methods [70] afford more opportunity to assess spatial and temporal patterns in community structure. In the face of global climate change and increasing anthropogenic pressures on groundwater ecosystems [71], analysis of spatial and temporal trends in groundwater communities will be increasingly important.

Supplementary Materials: The following are available online at https://www.mdpi.com/article/10 .3390 /d13060234/s1, Table S1: Raw species data for the San Marcos Artesian Well, including variables used in redundancy analysis. MEM1-4 are distance-based Moran's Eigenvector Maps values. Table S2: Stygobiont species lists for other diverse sites ( $>10$ stygobionts) in the Edwards and EdwardsTrinity Aquifers. Previously unpublished records of described species are included, along with specimen information, which serves as basis of the new record. Published records of undescribed/ undetermined taxa are included, but unpublished records of undescribed/ undetermined taxa are excluded. See below for published references.

Author Contributions: Conceptualization: B.T.H. and B.F.S.; methodology and analysis: B.T.H.; data acquisition: B.T.H., B.F.S., P.H.D., and J.R.G.; original draft preparation: B.T.H.; review and editing: B.T.H., B.F.S., P.H.D., and J.R.G. All authors have read and agreed to the published version of the manuscript.

Funding: This research had no external funding.

Institutional Review Board Statement: All research involving the collection of live animals was conducted in accordance with and approval from the Texas State University-San Marcos Institutional Animal Care and Use Committee (protocol \# 0318_0428_06, approved 28 April 2014).

Informed Consent Statement: Not applicable.

Data Availability Statement: The data presented in this study are openly available as supplementary files.

Acknowledgments: We appreciate the taxonomic expertise of William Coleman, Okan Külköylüoğlu, Kathryn Perez, Anna Camacho, Steve Fend, and Ian Smith. We dedicate this paper to Glen Longley for his years uncovering the hidden species of this occult environment. The views presented herein are those of the authors and do not necessarily represent those of the U.S. Fish and Wildlife Service.

Conflicts of Interest: The authors declare no conflict of interest.

\section{References}

1. Hinojosa, J.; Green, J.; Estrada, F.; Herrera, J.; Mata, T.; Phan, D.; Tanvir Pasha, A.B.M.; Matta, A.; Johnson, D.; Kapoor, V. Determining the Primary Sources of Fecal Pollution Using Microbial Source Tracking Assays Combined with Land-use Information in the Edwards Aquifer. Water Res. 2020, 184, 116211. [CrossRef]

2. Longley, G. The Edwards Aquifer: Earth's Most Diverse Groundwater Ecosystem? Int. J. Speleol. 1981, 11, 123-128. [CrossRef]

3. Boghici, R. Hydrogeology of Trinity-Edwards Aquifer of Texas and Coahuila in the Border Region. In Aquifers of the Edwards Plateau; Mace, R.E., Angle, E.S., Mullican, W.F., III, Eds.; Texas Water Development Board Report 360: Austin, TX, USA, 2004; pp. 91-114. 
4. Barker, R.A.; Bush, P.W.; Baker, E.T., Jr. Geologic History and Hydrogeologic Setting of the Edwards-Trinity Aquifer System, West-Central Texas. US Geol. Surv. Water Resour. Investig. Rep. 1994, 94, 1-51.

5. Maclay, R.W. Geology and Hydrology of the Edwards Aquifer in the San Antonio Area, Texas. US Geol. Surv. Water Resour. Investig. Rep. 1995, 95, 1-64.

6. Sharp, J.M.; Banner, J.L. The Edwards Aquifer: A Resource in Conflict. GSA Today 1997, 7, 1-9.

7. Schindel, G.M.; Gary, M. Hypogene Processes in the Balcones Fault Zone Segment of the Edwards Aquifer of South-Central Texas. In Hypogene Karst Regions and Caves of the World. Cave and Karst Systems of the World; Klimchouk, A., Palmer, A.N., De Waele, J., Auler, A.S., Audra, P., Eds.; Springer International Publishing AG: Gewerbestrasse, Switzerland, 2017; pp. 511-530.

8. Hutchins, B.T.; Schwartz, B.F.; Engel, A.S. Environmental Controls on Organic Matter Production and Transport Across SurfaceSubsurface and Geochemical Boundaries in the Edwards Aquifer, Texas, USA. Acta Carsologica 2013, 42, 245-259. [CrossRef]

9. Holsinger, J.R.; Longley, G. The Subterranean Amphipod Crustacean Fauna of an Artesian Well in Texas. Smithson. Contrib. Zool. 1980, 380, 1-62. [CrossRef]

10. Ogden, A.E.; Quick, R.A.; Rothermel, S.R. Hydrochemistry of the Comal, Hueco, and San Marcos Springs, Edwards Aquifer, Texas. In The Balcones Escarpment: Geology, Hydrology, Ecology and Social Development in Central Texas; Abbott, P.L., Woodruff, C.M., Jr., Eds.; Geological Society of America Annual Meeting: San Antonio, TX, USA, 1986; pp. 115-130.

11. Culver, D.C.; Sket, B. Hotspots of Subterranean Biodiversity in Caves and Wells. J. Cave Karst Stud. 2000, 62, 11-17.

12. Ulrich, C.J. A Contribution to the Subterranean Fauna of Texas. Trans. Am. Microsc. Soc. 1902, 23, 83-101. [CrossRef]

13. Benedict, J.E. Preliminary Descriptions of a New Genus and Three New Species of Crustaceans from an Artesian Well at San Marcos, Texas. Proc. U.S. Nat. Mus. 1896, 18, 615-617. [CrossRef]

14. Stejneger, L. Description of a New Genus and Species of Blind Tailed Batrachians from the Subterranean Waters of Texas. Proc. U.S. Nat. Mus. 1896, 18, 619-621. [CrossRef]

15. Holsinger, J.R. Two New Species of the Subterranean Amphipod Genus Mexiweckelia (Gammaridae) from Mexico and Texas, with Notes on the Origin and Distribution of the Genus. Assoc. Mex. Cave Stud. Bull. 1973, 5, 1-12.

16. Young, F.L.; Longley, G. A New Subterranean Aquatic Beetle from Texas (Coleoptera: Dytiscidae-Hydroporinae). Ann. Entomol. Soc. Am. 1976, 69, 787-792. [CrossRef]

17. Karnei, H.S., Jr. A Survey of the Subterranean Aquatic Fauna of Bexar County, Texas. Master's Thesis, Southwest Texas State University, San Marcos, TX, USA, 1978.

18. Külköylüoğlu, O.; Yavuzatmaca, M.; Akdemir, D.; Schwartz, B.F.; Hutchins, B.T. Description of a New Tribe Cabralcandonini (Candonidae, Ostracoda) from Karst Aquifers in Central Texas, U.S.A. J. Cave Karst Stud. 2019, 81, 136-151. [CrossRef]

19. Külköylüoğlu, O.; Akdemir, D.; Yavuzatmaca, M.; Schwartz, B.F.; Hutchins, B.T. Cypria lacrima sp. nov. A New Ostracoda (Candonidae, Crustacea) Species from Texas, USA. Zool. Stud. 2017, 56, e15. [PubMed]

20. Külköylüoğlu, O.; Yavuzatmaca, M.; Akdemir, D.; Schwartz, B.F.; Hutchins, B.T. Lacrimacandona n. gen. (Crustacea: Ostracoda: Candonidae) from the Edwards Aquifer, Texas (USA). Zootaxa 2017, 4277, 261-273. [CrossRef] [PubMed]

21. Külköylüoğlu, O.; Akdemir, D.; Yavuzatmaca, M.; Schwartz, B.F.; Hutchins, B.T. Rugosuscandona, a New Genus of Candonidae (Crustacea: Ostracoda) from Groundwater Habitats in Texas, North America. Species Divers. 2017, 22, 175-185. [CrossRef]

22. Külköylüoğlu, O.; Yavuzatmaca, M.; Akdemir, D.; Schwartz, B.F.; Hutchins, B.T. Ufocandona hannaleeae gen. et sp. nov. (Crustacea, Ostracoda) from an Artesian Well in Texas, USA. Eur. J. Taxon. 2017, 372, 1-18. [CrossRef]

23. Schwartz, B.F.; Nice, C.; Jenson, A.; Gibson, J.R. Final Report: Molecular and Morphological Analysis of Stygobromus sp. Near San Marcos, TX; Texas Parks and Wildlife Department: Austin, TX, USA, 2016.

24. Schwartz, B.F.; Nice, C.; Coleman, W. Final Report: Status Assessment and Ecological Characterization of the Texas Troglobitic Water Slate (Lirceolus smithii); Texas Parks and Wildlife Department: Austin, TX, USA, 2018.

25. Birdwell, J.E.; Engel, A.S. Variability in Terrestrial and Microbial Contributions to Dissolved Organic Matter Fluorescence in the Edwards Aquifer, Central Texas. J. Cave Karst Stud. 2009, 71, 144-156.

26. Gray, C.J.; Engel, A.S. Microbial Diversity and Impact on Carbonate Geochemistry Across a Changing Geochemical Gradient in a Karst Aquifer. ISME J. 2013, 7, 325-337. [CrossRef]

27. Hutchins, B.T.; Engel, A.S.; Nowlin, W.H.; Schwartz, B.F. Chemolithoautotrophy Supports Macroinvertebrate Food Webs and Affects Diversity and Stability in Groundwater Communities. Ecology 2016, 97, 1530-1542. [CrossRef]

28. Hutchins, B.T.; Schwartz, B.F.; Nowlin, W.H. Morphological and Trophic Specialization in a Subterranean Amphipod AssemBlage. Freshw. Biol. 2014, 59, 2447-2461. [CrossRef]

29. Fišer, C.; Blejec, A.; Trontelj, P. Niche-based Mechanisms Operating within Extreme Habitats: A Case Study of Subterranean Amphipod Communities. Biol. Lett. 2012, 8, 578-581. [CrossRef]

30. Ercoli, F.; Lefebvre, F.; Delangle, M.; Godé, N.; Caillon, M.; Raimond, R.; Souty-Grosset, C. Differing Trophic Niches of Three French Stygobionts and Their Implications for Conservation of Endemic Stygofauna. Aquat. Conserv. 2019, 29, $2193-2203$. [CrossRef]

31. Chávez-Solís, E.M.; Solís, C.; Simões, N.; Mascaró, M. Distribution Patterns, Carbon Sources and Niche Partitioning in Cave Shrimps (Atyidae: Typhlatya). Sci. Rep. 2020, 10, 12812. [CrossRef] [PubMed]

32. Dole-Olivier, M.-J.; Marmonier, P.; Creuzé des Châtelliers, M.; Martin, D. Interstitial Fauna Associated with the Alluvial FloodPlains of the Rhône River (France). In Groundwater Ecology; Gibert, J., Danielopol, D.L., Stanford, J.A., Eds.; Academic Press: San Diego, CA, USA, 1994; pp. 313-346. 
33. Pipan, T.; Christman, M.C.; Culver, D.C. Dynamics of Epikarst Communities: Microgeographic Pattern and Environmental Determinants of Epikarst Copepods in Organ Cave, West Virginia. Am. Mid. Nat. 2006, 156, 75-87. [CrossRef]

34. Gibert, J.; Vervier, P.; Malard, F.; Laurent, R.; Reygrobellet, J.-L. Dynamics of Communities and Ecology of Karst Ecosystems: Example of Three Karsts in Eastern and Southern France. In Groundwater Ecology; Gibert, J., Danielopol, D.L., Stanford, J.A., Eds.; Academic Press: San Diego, CA, USA, 1994; pp. 425-450.

35. Lorenzo, T.D.; Cipriani, D.; Fiasca, B.; Rusi, S.; Galassi, D.M.P. Groundwater Drift Monitoring as a Tool to Assess the Spatial Distribution of Groundwater Species in Karst Waters. Hydrobiologia 2018, 813, 137-156. [CrossRef]

36. Opalički Slabe, M. Patterns in Invertebrate Drift from an Alpine Karst Aquifer over a One Year Period. Acta Carsologica 2015, 44, 265-278. [CrossRef]

37. Gibson, J.R.; Harden, S.J.; Fries, J.N. Survey and Distribution of Invertebrates from Selected Springs of the Edwards Aquifer in Comal and Hays Counties, Texas. Southwest. Nat. 2008, 53, 74-84. [CrossRef]

38. Trontelj, P.; Douady, C.J.; Fišer, C.; Gibert, J.; Gorički, Š.; Lefébure, T.; Sket, B.; Zakšek, V. A Molecular Test for Cryptic Diversity in Ground Water: How Large are Ranges of Macro-stygobionts? Freshw. Biol. 2009, 54, 727-744. [CrossRef]

39. Stoch, F.; Galassi, D.M.P. Stygobiontic Crustacean Species Richness: A Question of Numbers, a Matter of Scale. Hydrobiologia 2010, 653, 217-234. [CrossRef]

40. Trontelj, P. Structure and Genetics of Cave Populations. In Cave Ecology; Moldovan, O.T., Kováč, L., Halse, S., Eds.; Springer Nature: Cham, Switzerland, 2018; pp. 269-296.

41. Pipan, T.; Culver, D.C.; Papi, F.; Kozel, P. Partitioning Diversity in Subterranean Invertebrates: The Epikarst Fauna of Slovenia. PLoS ONE 2018, 13, e0195991. [CrossRef]

42. Trajano, E.; de Carvalho, M.R. Towards a Biologically Meaningful Classification of Subterranean Organisms: A Critical Analysis of the Schiner-Racovitza System from a Historical Perspective, Difficulties of Its Application and Implications for Conservation. Subterr. Biol. 2017, 22, 1-26. [CrossRef]

43. Borcard, D.; Gillet, F.; Legendre, P. Numerical Ecology with R; Springer Science+Business Media, LLC.: New York, NY, USA, 2011.

44. Kollaus, K.A.; Bonner, T.R. Habitat Associations of a Semi-arid Fish Community in a Karst Spring-fed Stream. J. Arid Environ. 2012, 76, 72-79. [CrossRef]

45. U.S. Geological Survey. National Water Information System Data Available on the World Wide Web (USGS Water Data for the Nation). Available online: https:/ / waterdata.usgs.gov/tx/nwis/uv/?site_no=08170500\&PARAmeter_cd=00065,00060 (accessed on 19 November 2020). [CrossRef]

46. Zappitello, S.J.; Johns, D.A.; Hunt, B.B. Summary of Groundwater Tracing in the Barton Springs Edwards Aquifer from 1996 to 2017. In Report \# DR-19-04; Barton Springs Edwards Aquifer Conservation District: Austin, TX, USA, 2019.

47. Legendre, P.; Gauthier, O. Statistical Methods for Temporal and Space-time Analysis of Community Composition Data. Proc. R. Soc. B Biol. Sci. 2014, 281, 20132728. [CrossRef] [PubMed]

48. Cardoso, P.; Rigal, F.; Carvalho, J.C. BAT-Biodiversity Assessment Tools, an R Package for the Measurement and Estimation of Alpha and Beta Taxon, Phylogenetic and Functional Diversity. Methods Ecol. Evol. 2015, 6, 232-236. [CrossRef]

49. Jaume, D. Global Diversity of Spelaeogriphaceans \& Thermosbaenaceans (Crustacea; Spelaeogriphacea \& Thermosbaenacea) in Freshwater. Hydrobiologia 2008, 595, 219-224.

50. Sket, B. Hirudinea. In Stygofauna Mundi; Botosaneanu, L., Ed.; E.J. Brill \& Dr. W. Backhuys: Leiden, The Netherland, 1986; pp. 250-253.

51. Kanda, K.; Gomez, R.A.; Driesche, R.V.; Miller, K.B.; Maddison, D.R. Phylogenetic Placement of the Pacific Northwest Subterranean Endemic Diving Beetle Stygoporus oregonensis Larson \& LaBonte (Dytiscidae, Hydroporinae). Zootaxa 2016, 632, 75-91.

52. Moravec, F.; Huffman, D.G. Three New Helminth Species from Two Endemic Plethodontid Salamanders, Typhlomolge rathbuni and Eurycea nana, in Central Texas. Folia Parasitol. 2000, 47, 186-194. [CrossRef]

53. Kenk, R. Freshwater Triclads (Turbellaria) of North America, IX: The Genus Sphalloplana. Smithson. Contrib. Zool. 1977, $246,1-38$. [CrossRef]

54. Alvear, D.; Diaz, P.H.; Gibson, J.R.; Jones, M.; Perez, K.E. An Unusually Sculptured New Species of Phreatodrobia Hershler \& Longley (Mollusca: Caenogastropoda: Cochliopidae) from Central Texas. Zootaxa 2020, 4810, 143-152.

55. Hershler, J.R.; Longley, G. Phreatic Hydrobiids (Gastropoda: Prosobranchia) from the Edwards (Balcones Fault Zone) Aquifer Region, South-Central Texas. Malacologia 1986, 27, 127-172.

56. Külköylüoğlu, O. A New Genus and Species in the Ostracod Family Candonidae (Crustacea: Ostracoda) from Texas, USA. J. Nat. Hist. 2018, 52, 1295-1310. [CrossRef]

57. Camacho, A.I.; Hutchins, B.; Schwartz, B.F.; Dorda, B.A.; Casado, A.; Rey, I. Description of a New Genus and Species of Bathynellidae (Crustacea: Bathynellacea) from Texas Based on Morphological and Molecular Characters. J. Nat. Hist. 2018, 52, 29-51. [CrossRef]

58. Hutchins, B.T.; Schwartz, B.F.; Coleman, W.T. Three New Microcerberids (Isopoda, Microcerberidae) from Subterranean Freshwater Habitats in Texas, U.S.A. (In review)

59. Schwartz, B.F.; Hutchins, B.T.; Schwartz, Z.G.; Hess, A.J.; Bonett, R.M. Cirolanides wassenichae sp. nov., a Freshwater, Subterranean Cirolanidae (Isopoda, Cymothoida) with Additional Records of Other Species from Texas, United States. Zootaxa 2019, 4543, 498-514. [CrossRef] 
60. Zara Environmental LLC. Final Report: Hays County Karst Invertebrate Distribution and Cave Development; Texas Parks and Wildlife Department: Austin, TX, USA, 2010.

61. World of Copepods. Available online: www.marinespecies.org/copepoda (accessed on 11 May 2021).

62. Carvalho, J.C.; Cardoso, P.; Borges, P.A.V.; Schmera, D.; Podani, J. Measuring Fractions of Beta Diversity and Their Relationships to Nestedness: A Theoretical and Empirical Comparison of Novel Approaches. Oikos 2013, 122, 825-834. [CrossRef]

63. Culver, D.C.; Pipan, T. The Biology of Caves and Other Subterranean Habitats, 2nd ed.; Oxford University Press: Oxford, UK, 2019.

64. Cardinale, B.J.; Bennett, D.M.; Nelson, C.E.; Gross, K. Does Productivity Drive Diversity or Vice Versa? A Test of the Multivariate Productivity-diversity Hypothesis in Streams. Ecology 2009, 90, 1227-1241. [CrossRef]

65. Eme, D.; Zagmajster, M.; Fišer, C.; Galassi, D.; Marmonier, P.; Stoch, F.; Cornu, J.-F.; Oberdorff, T.; Malard, F. Multi-causality and Spatial Non-stationarity in the Determinants of Groundwater Crustacean Diversity in Europe. Ecography 2015, 38, 531-540. [CrossRef]

66. Culver, D.C.; Deharveng, L.; Bedos, A.; Lewis, J.J.; Madden, M.; Reddell, J.R.; Sket, B.; Trontelj, P.; White, D. The Mid-latitude Biodiversity Ridge in Terrestrial Cave Fauna. Ecography 2006, 29, 120-128. [CrossRef]

67. Toomey, R.S., III; Blum, M.D.; Valastro, S., Jr. Late Quaternary Climates and Environments of the Edwards Plateau, Texas. Glob. Planet. Chang. 1993, 7, 299-320. [CrossRef]

68. Cardoso, P.; Borges, P.A.V.; Veech, J.A. Testing the Performance of Beta Diversity Measures Based on Incidence Data: The Robustness to Undersampling. Divers. Distrib. 2009, 15, 1081-1090. [CrossRef]

69. Malard, F.; Boutin, C.; Camacho, A.I.; Ferreira, D.; Michel, G.; Sket, B.; Stoch, F. Diversity Patterns of Stygobiotic Crustaceans Across Multiple Spatial Scales in Western Europe. Freshw. Biol. 2009, 54, 756-776. [CrossRef]

70. Cáceres, M.D.; Coll, L.; Legendre, P.; Allen, R.B.; Wiser, S.K.; Fortin, M.-J.; Condit, R.; Hubbell, S. Trajectory Analysis in Community Ecology. Ecol. Monogr. 2019, 89, e01350. [CrossRef]

71. Mammola, S.; Cardoso, P.; Culver, D.C.; Deharveng, L.; Ferreira, R.L.; Fišer, C.; Galassi, D.M.P.; Griebler, C.; Halse, S.; Humphreys, W.H.; et al. Scientists' Warning on the Conservation of Subterranean Ecosystems. Bioscience 2019, 69, 641-650. [CrossRef] 